УДК 78.087.68:004.9
DОI https://doi.org/10.31723/2524-0447-2021-32-1-29

Оксана Валеріївна Сухецька

ORCID: 0000-0003-2425-4745

старший викладач кафедри музикознавства

та вокально-хорового мистецтва

Уманського держсавного педагогічного університету

імені Павла Тичини

oksana.prokulevych@ukr.net

\title{
ВІРТУАЛЬНИЙ ХОР: ОКРЕМІ ПИТАННЯ ТЕОРІЇ І ПРАКТИКИ (ДО ПОСТАНОВКИ ПРОБЛЕМИ)
}

Метою роботи $є$ дослідження явища віртуального хору та алгоритму його практичної реалізації на матеріалі шостого віртуального хору Еріка Вітакера «Sing Gently» і віртуальних проєктів, реалізованих народним аматорським колективом профспілок України «Молодіжний камерний хор» Уманського державного педагогічного університету імені Павла Тичини.

Завдання роботи - відобразити детальний опис механізму створення віртуального артефакту та викласти його у покрокових завданнях, які можуть становити орієнтовний план дій для майбутнього учасника будь-якого хорового віртуального проєкту; визначити необхідне матеріально-технічне забезпечення хориста для участі у таких проєктах; окреслити основні етапи роботи, включаючи характеристику виявлених шляхом спостереження та експерименту труднощів та шляхів їх подолання; здійснити порівняльний аналіз методів реалізації віртуальних проєктів Еріка Вітакера, Олени Слободиської, Юлії Пучко-Колесник, Рубена Толмачова і Оксани Сухецької (автора статті).

Методологія дослідження спирається на системно-аналітичні та емпіричні методи.

Наукова новизна. Обгрунтовується доцільність створення та творчої реалізації віртуального хору як новітнього вектора розвитку сучасної хорової творчості; виявлена та проаналізована специфіка виконавської та суто диригентської діяльності в означеному форматі; визначені та обгрунтовані практично-методичні шляхи роботи над віртуальним хоровим твором (на прикладі шостого віртуального хору Еріка Вітакера «Sing Gently»).

Висновки. Створення віртуального хору та творча реалізація віртуального проєкту від народження ідеї до ї̈ втілення - це багатоетапний складний творчий процес, що вимагає розширення компетентностей керівника хорового колективу та хористів, а також спонукає до за-

(C) Сухецька О. В., 2021 
лучення спеціалістів із галузі інформаційних технологій $і$ відповідного програмного та матеріально-технічного забезпечення або набуття навичок роботи з таким програмним забезпеченням самим керівником віртуального хорового колективу.

Ключові слова: сучасна хорова творчість, віртуальний хор, віртуальний проєкт, Кіниугі.

Sukhetska Oksana Valeriivna, Senior Lecturer at the Department of Musicology and Vocal and Choral Arts of Pavlo Tychyna Uman State Pedagogical University

Virtual choir: certain issues of theory and practice (to the statement of the problem)

Research objective. The purpose of the work is to study the phenomenon of virtual choir and the algorithm of its practical implementation on the material: Eric Whitacre's sixth virtual choir "Sing Gently" and virtual projects implemented by the amateur group of trade unions "Youth chamber choir" of the Pavlo Tychyna Uman State Pedagogical University.

Tasks of work: display a detailed description of the mechanism for creating a virtual artifact and set it out in step-by-step tasks that can represent an indicative action plan for the future participant of any choral virtual project. Determine the necessary logistics of the chorister to participate in such projects. Outline the main stages of work, including the characteristics of the identified, by observation and experiment, the difficulties and ways to overcome them. Carry out a comparative analysis of the implementation of virtual projects by Eric Whitacre, Olena Slobodyska, Yuliia Puchko-Kolesnyk and Ruben Tolmachov and Oksana Sukhetska. The methodology of the research is based on the system-analytical and empirical methods. The scientific novelty - the expediency of creation and creative realization of virtual choir as the newest vector of development of modern choral creativity is substantiated; identified and analyzed the specifics of performing and purely conducting activities in the specified format; identified and substantiated practical and methodological ways of working on a virtual choral work (on the example of the sixth virtual choir of Eric Whitacre's "Sing Gently"). Conclusions. Creating a virtual choir and creative implementation of a virtual project from the birth of an idea to its implementation is a multi-stage complex creative process that requires expanding the competencies of the choir leader and choristers, and encourages the involvement of specialists in information technology and software and hardware or acquiring skills to work with such software by the leader of the virtual choir.

Key words: modern choral art, virtual choir, virtual project, Kintsugi.

Актуальність теми дослідження. Сучасний етап розвитку музичної культури ставить перед митцями нові виклики та завдання. Одним із новітніх напрямів стала реалізація творчого задуму в інтернет-просторі, розширивши поняття про концертовий простір у хоровій творчості. В авангарді цього 
напряму стоїть феномен віртуального хору, засновником якого справедливо вважається Е. Вітакер. Проєкт Віртуального хору розпочався як простий експеримент дванадцять років тому (у 2009 році). Під час пандемії Ерік Вітакер написав твір «Sing Gently» спеціально для Віртуального хору 6. Дивовижно, що всі розуміли його особливе призначення впродовж більше десятиліття - єднання людей з усього світу через музику. Це створило для усіх нас особливий виклик і одночасно комфорт в умовах пандемії. Тому теоретичне та методичне опрацювання цього феномену видається надзвичайно актуальним та своєчасним у контексті сучасного хорознавства.

Метою дослідження є визначення етапів створення віртуального проєкту на матеріалах: шостого віртуального хору Еріка Вітакера «Sing Gently», віртуальних проєктів народного аматорського колективу профспілок України «Молодіжний камерний хор» Уманського державного педагогічного університету імені Павла Тичини під керівництвом Оксани Сухецької, («Тропар до Пресвятої Богородиці» (музика Ганни Гаврилець) та щедрівка «Ой, в лужку, в лужку, на жовтім піску» (обробка Олександра Некрасова)), наймасштабнішого віртуального хору України під керівництвом Олени Слободиської «Не стій, вербо, над водою» (українська народна пісня в обробці Віктора Грицишина, перекладу Миколи Гобдича), хору Національної музичної академії України імені П.І. Чайковського разом із Камерним дівочим хором Київської середньої спеціалізованої школи-інтернату імені М.В. Лисенка під керівництвом Рубена Толмачова та Юлії Пучко-Колесник «Ми» (твір китайського композитора Лі Сяобіна).

Наукова новизна. Обгрунтування необхідності створення та творчої реалізації віртуального хору як провідного вектора популяризації та розвитку хорового виконавського мистецтва на сучасному етапі на матеріаліах: шостого віртуального хору Еріка Вітакера «Sing Gently», віртуальних проєктів народного аматорського колективу профспілок України «Молодіжний камерний хор» Уманського державного педагогічного університету імені Павла Тичини під керівництвом Оксани Сухецької («Тропар до Пресвятої Богородиці» (музика Ганни Гаврилець) та щедрівка «Ой, в лужку, в лужку, на жовтім піску» (обробка Олександра Некрасова)), наймасштабнішого віртуального хору України під керівництвом Олени Слободиської «Не стій, вербо, над водою» (українська народна пісня в 
обробці Віктора Грицишина, перекладення Миколи Гобдича), хору Національної музичної академії України імені П.І. Чайковського разом із Камерним дівочим хором Київської середньої спеціалізованої школи-інтернату імені М.В. Лисенка під керівництвом Рубена Толмачова та Юлії Пучко-Колесник «Ми» (твір китайського композитора Лі Сяобіна).

Виклад основного матеріалу. Ерік Вітакер є одним із найпопулярніших американських композиторів нашого часу, диригентом, спікером, автором численних хорових, оркестрових та духових композицій, із березня 2016 року - першим артистом-резидентом Лос-Анджелеського хору в Концертному залі імені Волта Діснея. Його перший альбом як композитора та диригента - «Light and Gold»- отримав 54 щорічну нагороду Греммі - престижну нагороду американської Академії звукозапису за краще хорове виконання 2011 року [1].

Віртуальний хор є одним із найбільш амбітних, незвичних і цікавих проєктів Еріка Вітакера. Надихнула композитора на створення віртуального хору дівчина Брітлін Лозі, котра записала звернення до Еріка, в якому виконала партію сопрано до композиції «Sleep» (2000 р.) [7].

Сутність цього фантастичного проєкту полягає в такому: сотні людей (на початку його реалізації), а пізніше - десятки тисяч осіб з усього світу об'єднуються для спільної творчості. Ерік Вітакер створив Віртуальний хор із простим запитанням: чи можливо робити красиву музику разом (незалежно від того, наскільки ми далеко один від одного)? Після декількох віртуальних хорових проєктів за участі понад 20000 співаків із 124 різних країн відповідь є однозначною - «так».

Нині Ерік Вітакер реалізував уже 6 таких проєктів. Так, наприклад, спеціально для Віртуального хору 6 під час пандемії Ерік Вітакер написав твір «Sing Gently».

Зважаючи на серйозний технічний прогрес за останнє десятиліття, особливо за поточний рік, можна зробити висновок, що певні форми комунікації в суспільстві цілком замінили чи ж доповнили спілкування наживо, але мистецтво вимагає факту присутності, що слід уважати аксіомою. Сьогодні жодна професійна студія світу з найпотужнішим обладнанням не може забезпечити одночасне якісне передання звуку та зображення для організації такого рівня дистанційного хорового виконання, яке можна наблизити до живого спільного музикування «тут і зараз, разом». 
Ідея віртуального хору Еріка Вітакера - це тимчасовий компроміс чи новий жанр? На це питання можна відповісти, пройшовши тривалу перевірку часом. Зараз будемо до нього ставитись як до феномену нашого часу. Нижче розглянемо процес народження такого віртуального хорового колективу та особливості його творчої реалізації.

Алгоритм створення цього артефакту полягає у таких положеннях: композитор-диригент Ерік Вітакер здійснює відеозапис власного диригування у супроводі фортепіано (для досліджуваного нами проєкту партію фортепіано виконав Сем Глікліх зі школи Колберн) та високої якості ансамблевого звучання всіх партій хору (в цьому творі ними є чотири голоси, які виконали професійні співаки хору Еріка Вітакера (Eric Whitacre Singers): Грейс Девідсон, Марту Маклорінан, Бен Хімас та Грег Скідмор.

Організаторами також створені відеозаписи, в яких динамічно підсилений той чи інший голос, що суттєво полегшує процес розучування хорової партії. Створено сайт, де охочі стати учасниками проєкту реєструються та отримують вільний доступ до цілком вичерпної інформації, наданої автором та його командою. Успішно зареєстровані учасники ознайомлюються 3 рекомендаціями диригента та, погодившись із політикою використання нот, завантажують нотний матеріал для роботи над своєю партією. Відомо, що завантажений учасником матеріал на ресурс не використовуватиметься як окремий відео- чи аудіозапис, а виключно як частина спільного виконання у фільмі «Sing Gently». На вказаному сайті також є інформативний розділ - центр онлайн-ресурсів для хористів. Його контент містить вокальні вправи для співаків, цінні поради від композиторів, виконавців, педагогів. Матеріали постійно оновлюються та не мають жодних обмежень у використанні.

Розміщені також чіткі вказівки щодо процедури запису власного відео, які викладені композитором як особисте звернення до кожного хориста так:

1. «Плескайте в долоні один раз, у зазначений час - це стане точкою відліку в процесі роботи з аудіо та відео під час синхронізації матеріалів. Це досить важливий момент, адже суттєво полегшує роботу режисера в процесі створення фільму.

2. Шодо матеріально-технічного забезпечення, то вам необхідна наявність двох пристроїв: одного - для перегляду 
та прослуховування диригентського відео, а іншого - для запису виконання. Це може бути смартфон, портативний комп'ютер чи будь-який інший пристрій для відтворення, а також навушники, щоб можна було прослуховувати запис, але записувати лише свій голос. До проєкту Віртуальний хор 6 приймаються лише індивідуальні записи: сопрано, альт, тенор, бас або виконання жестовою мовою.

3. Рекомендується записувати відео перед стіною чи іншим простим тлом, одяг має бути без візерунків та логотипів. Слід переконатися, що обличчя достатньо освітлене, а для цього слід використовувати будь-які світильники або природне освітлення.

4. Рекомендовано здійснювати запис у тихому приміщенні, за зачиненими дверима, без сторонніх звуків. Вимкнути всі прилади, які можуть створювати гул чи шум. Пристрій, на який здійснюватиметься запис, слід зафіксувати, щоб мінімізувати його рух.

5. Якщо запис здійснюється на телефон, то рекомендується увімкнути беззвучний режим, щоб запис не перервався дзвінком чи повідомленням.

6. Необхідно підключити навушники до пристрою під час виконання, на якому прослуховуватиметься запис. Важливо переконатися, що запис здійснюється горизонтально, а обличчя - посередині кадру.

7. Бажано заздалегідь обрати формат та якість запису на пристрої mp4 720, що заощадить час, витрачений на конвертацію файла після зйомки.

8. Спершу увімкніть власний запис, а потім розпочніть відтворення диригентського відео. Після завершення співу не потрібно вимикати запис близько чотирьох рахунків (подумки!).

9. Наостанок перегляньте власне відео і у разі задоволення результатом завантажте його, заздалегідь переконавшись, що файл відповідає заявленим вимогам щодо формату (MP4 або MPEG4 (бажано), MOV, WMV або AVI), а його розмір не перевищує 200 Мб. Якщо файл потребує стиснення, то слід використати потрібну програму» [2].

Після успішного завантаження і прийому матеріалу організаторами, учасник отримує лист-підтвердження на електронну пошту та власний іменний сертифікат. Далі розпочинається робота автора проєкту та його команди, яка полягає в 
обробці звуку з видалення сторонніх немузичних звуків та їх вирівнювання перед сполученням:

1. Обтинання відео до потрібних розмірів та форм для включення у фільм. Відбувається творчий робочий процес над створенням фільму.

2. Створюється та перевіряється список імен усіх учасників проєкту, який додається наприкінці фільму.

3. Здійснюється об'єднання всіх відеодоріжок у злагоджене хорове звучання.

Як зазначав Е. Вітакер у своїх численних зверненнях до учасників проєкту, одним із творчих натхнень у створенні образів для Віртуального хору $6 є$ Кінцугі - японське мистецтво реставрації розбитих гончарних виробів шляхом виправлення зламів за допомогою запиленого лаку або лаку, змішаного з порошкоподібним золотом. Ремонт цілком видимий і виріб виглядає, можливо, красивішим, ніж раніше. Така концепція була запропонована дизайнерською студією 59 Productions. Студія відзначена найпрестижнішою театральною нагородою у Великій Британії, яку з 1977 року вручає Товариство Лондонського театру (засноване 1908 року як Товариство театрів Вест-Енду). У 1984 році премію названо на честь британського актора Лоуренса Олів’є (1907-1989). Також студія 59 Productions - володар «Тоні» [3] - популярної премії, яку щорічно присуджують за досягнення у сфері американського театру, включаючи музичний театр (численні постановки на Бродвеї, Нью-Йорк). Повна офіційна назва премії «Премія Антуанетти Перрі за театральну досконалість» (англ. Antoinette Perry Award for Excellence in Theatre). Свою назву премія отримала на честь американської акторки і режисерки Антуанетти Перрі (1888-1946). Премія присуджується спільнотою, що складається з приблизно 830 компетентних осіб. Премія «Тоні» була заснована в 1947 і вважається театральним еквівалентом кінематографічного «Оскара», музичної «Греммі» і телевізійної «Еммі». Лауреатами премії ставало багато відомих акторів та діячів театру [4]. Мистецтво Кінцугі дуже резонує сьогодні у творі Еріка «Sing Gently».

Таким чином, ми отримуємо красивий і професійно змонтований відеокліп та вражаюче потужне хорове звучання десятків тисяч голосів, яке сягає більше 10 мільйонів переглядів.

Уперше такий музичний ансамбль зібрався у 2009 році, щоб виконати твір «Lux Aurum que», тоді до проєкту долучи- 
лися 185 хористів із 12 країн. У 2020 році до віртуального хору Еріка Вітакера (на композицію «Sing Gently») долучилися 17572 учасники зі 129 країн світу, а зареєструвалися на цей проєкт 41820 осіб зі 145 країн світу [2]. Чисельність аудиторії, яку вдалося охопити цим мистецьким проєктом, вражає. Хоровий спів стає ближчим до користувачів інтернет-мережі - найбільшої концертової зали світу, набираючи обертів на шляху до популярності та визнання широкими колами пересічних громадян.

Протягом останнього року-півтора, цей напрям отримав широке розповсюдження і в Україні. Автором подібного наймасштабнішого проєкту України є Олена Слободиська. Під iii керівництвом хористи виконали українську народну пісню в обробці Віктора Грицишина, перекладу Миколи Гобдича «Не стій, вербо, над водою» [8]. 11 травня 2020 року встановлено національний рекорд України у категорії «Найбільший віртуальний хор в Україні» [5]. 111 українців із 15 областей України та з різних країн світу стали частиною єдиного хорового колективу. Організатори проєкту - п'ятеро талановитих молодих людей із Вінниці, Києва, Харкова та Кодими - отримали відповідні посвідчення рекордсменів України Національного проєкту «Книга рекордів України», а учасники були нагороджені дипломами.

Яскравим прикладом є масштабний проєкт хору Національної музичної академії України імені П.І. Чайковського, який разом із Камерним дівочим хором Київської середньої спеціалізованої школи-інтернату імені М.В. Лисенка (під керівництвом Рубена Толмачова та Юлії Пучко-Колесник) записав відео на композицію «Ми» китайського композитора Лі Сяобіна. Участь у цьому проєкті взяли 212 відомих музикантів із 20 країн, 302 професори та студенти з 27 консерваторій, розташованих у 21 країні світу [6].

Кілька віртуальних проєктів створив народний аматорський колектив профспілок України «Молодіжний камерний хор» Уманського державного педагогічного університету імені Павла Тичини під керівництвом Оксани Сухецької, серед яких: «Тропар до Пресвятої Богородиці» (музика Ганни Гаврилець) [9] та щедрівка «Ой, в лужку, в лужку, на жовтім піску» (обробка Олександра Некрасова) [10]. Керівництво проєктами (включно з обробкою і зведенням звуку) здійснювала художній керівник колективу, а відеомонтаж належить 
артистці хору. Так, мала місце робота в комп'ютерних програмах і додатках (Finale, Melodyne, Adobe Audition та VN).

Висновки. Створення віртуального хору та творча реалізація віртуального проєкту від народження ідеї до ії втілення це багатоетапний складний творчий процес, що вимагає розширення компетентностей керівника хорового колективу та хористів, а також спонукає до залучення спеціалістів із галузі інформаційних технологій і відповідного програмного та матеріально-технічного забезпечення або до набуття навичок роботи з названим програмним забезпеченням самим керівником віртуального хорового колективу. До таких програм належать: Finale, Melodyne, Adobe Audition та VN.

Одним 3 основних етапів роботи $\epsilon$ створення такого ресурсу, який забезпечить майбутнього артиста віртуального хору всіма необхідними матеріалами для успішної реалізації віртуального проєкту. Контент такого сайту чи каналу має містити вичерпну інформацію, зокрема: вокальні вправи, розспівки, цінні поради шодо роботи зі звуком, роз'яснення виконавських особливостей відтворення тих чи інших нюансів тощо. Важливо забезпечити доступ до спілкування з керівником проєкту, який повинен надавати вчасну й повну відповідь на будь-які питання хористів.

Віртуальний хор може складатися зі співаків, які раніше вже працювали разом у колективі, наживо (хор НМАУ імені П.І. Чайковського разом із Камерним дівочим хором КССМШ-інтернату імені М.В. Лисенка під керівництвом Р. Толмачова та Ю. Пучко-Колесник (частково); «Молодіжний камерний хор» УДПУ імені Павла Тичини, О. Сухецької). Проте твори, обрані для віртуальних проєктів, артисти «Молодіжного камерного хору» вивчали самостійно вже в умовах пандемії, ізольовано від інших учасників та керівника. Співтворчість здійснювалася виключно засобами дистанційного зв'язку, що й визначає цей артефакт як віртуальний.

Існує й інший варіант: виконавці ніколи раніше не зустрічалися наживо, а лише дистанційно (віртуальні проєкти Е. Вітакера та О. Слободиської). Такі умови теж впливають на якість кінцевого результату. Безперечно, керівники таких колективів мусять забезпечувати своїх віртуальних хористів значною частиною роз'яснювальних матеріалів, аби максимально доступно донести до виконавців власні побажання щодо виконання. Також є різниця у складі колективів (ама- 
тори чи професіонали), в технічних умовах (професійна робота звукорежисерів, it-спеціалістів чи обробка власними силами) тощо.

Відкритим залишається питання щодо специфіки роботи керівника віртуального хору та артиста такого віртуального хорового колективу. Вважаємо, що доцільним є визначення змінного та незмінного у практичній діяльності хору і віртуального хору, диригента і віртуального диригента, а також хориста і віртуального хориста. Подальших наукових розвідок та досліджень потребують поняття «віртуальний хор», «віртуальний диригент» та «артист віртуального хору». Також $\epsilon$ потреба експлікувати ці поняття та визначити вектори розвитку віртуального хору як феномену нашого часу в контексті розвитку хорового виконавського мистецтва.

\section{СПИСОК ЛІТЕРАТУРИ}

1. 2011 GRAMMY WINNERS. 54th Annual GRAMMY Awards (2011). URL: https://www.grammy.com/grammys/awards/54th-annualgrammy-awards-2011 (дата звернення: 06.11.2020).

2. Eric Whitacres Virtual Choir 6. URL: https://virtualchoir6.com/ (дата звернення: 06.11.2020).

3. Winners (59 productions). 2015 / Scenic design (musical). URL: https://www.tonyawards.com/winners/?q=59 (дата звернення: 06.11.2020).

4. An Award For Excellence. URL: https://www.tonyawards.com/ history/our-history/ (дата звернення: 06.11.2020).

5. Книга рекордів України. URL: https://www.record.org.ua/ 2020/05/11/stayhome-i-spivaj-na-rekord-u-mysteczkomu-proyektivirtualnyj-hor-v-ukrayini/ (дата звернення: 16.01.2021).

6. Новий музичний проект об'єднав музикантів з усього світу. URL: https://knmau.com.ua/novij-muzichnij-proekt-ob-yednavmuzikantiv-z-usogo-svitu/ (дата звернення: 27.01.2021).

7. Sleep - Eric Whitacre - Message and Singing from Britlin. URL: https://www.youtube.com/watch?v=3xGBWhWgydw (дата звернення: 22.02.2021).

8. «Не стій, вербо, над водою» - Віртуальний хор в Україні Рекорд України. URL: https://www.youtube.com/watch?v=jOjDv5ttqeQ (дата звернення: 22.02.2021).

9. Гаврилець Г. «Тропар до Пресвятої Богородиці». URL: https://www.youtube.com/watch?v=E2nH2C0ONdI (дата звернення: 22.02.2021).

10. Некрасов О. «Ой в лужку, в лужку, на жовтім піску». URL: https://www.youtube.com/watch?v=3ih5DPASPNM (дата звернення: 22.02.2021). 


\section{REFERENCES}

1. 2011 GRAMMY WINNERS. 54th Annual GRAMMY Awards (2011). URL: https://www.grammy.com/grammys/awards/54th-annualgrammy-awards-2011 (дата звернення: 06.11.2020).

2. Eric Whitacres Virtual Choir 6. URL: https://virtualchoir6.com/ (дата звернення: 06.11.2020).

3. Winners (59 productions). 2015 / Scenic design (musical). URL: https://www.tonyawards.com/winners/?q=59 (дата звернення: 06.11.2020).

4. An Award For Excellence. URL: https://www.tonyawards.com/ history/our-history/ (дата звернення: 06.11.2020).

5. Book of records of Ukraine. URL: https://www.record.org.ua/ 2020/05/11/stayhome-i-spivaj-na-rekord-u-mysteczkomu-proyektivirtualnyj-hor-v-ukrayini/ (дата звернення: 16.01.2021).

6. The new music project brings together musicians from around the world. URL: https://knmau.com.ua/novij-muzichnij-proekt-ob-yednavmuzikantiv-z-usogo-svitu/ (дата звернення: 27.01.2021).

7. Sleep - Eric Whitacre - Message and Singing from Britlin. URL: https://www.youtube.com/watch? $v=3 x$ GBWhWgydw (дата звернення: 22.02.2021).

8. «Don't stand, willow, over the water» - Virtual choir in Ukraine - Record of Ukraine. URL: https://www.youtube.com/ watch?v=jOjDv5ttqeQ (дата звернення: 22.02.2021).

9. H. Havrylets. «Troparion to the Blessed Virgin». URL: https://www.youtube.com/watch? $v=E 2 n H 2 C 0 O N d I$ (дата звернення: 22.02.2021).

10. O. Nekrasov. «Oh in the meadow, in the meadow, on the yellow sand». URL: https://www.youtube.com/watch?v=3ih5DPASPNM (дата звернення: 22.02.2021). 